\title{
UJI AKTIVITAS PENYUBUR RAMBUT GEL KOMBINASI EKSTRAK AIR TEH HIJAU DAN HERBA PEGAGAN
}

\section{HAIR GROWTH ACTIVITY TEST OF GEL COMBINATION OF GREEN TEA AND GOTUKOLA HERB WATER EXTRACT}

\author{
Lela Sulastri ${ }^{1}$, Teti Indrawati ${ }^{2}$, Shely Taurhesia ${ }^{2}$ \\ ${ }^{1}$ Sekolah Tinggi Farmasi Muhammadiyah Cirebon \\ Jl Cideng Indah no 3 Cirebon \\ ${ }^{2}$ Fakultas Farmasi Universitas Pancasila \\ Srengseh Sawah, Jagakarsa, Jakarta
}

Submitted: 16 April 2019

Reviewed: 26 April 2019

Accepted: 12 September 2019

\begin{abstract}
ABSTRAK
Rambut sehat mempunyai siklus pertumbuhan rambut yang panjang dan kelembaban yang cukup dimana pertumbuhan rambut terjadi karena sel-sel daerah matriks atau umbi rambut secara terus menerus membelah. Bahan alam yang diperkirakan berpotensi dalam pertumbuhan rambut adalah daun teh hijau (Camellia sinensis (L) dan herba pegagan (Centella asiatica (L) Urban). Dalam penelitian ini ekstrak air daun teh hijau 5\% dan herba pegagan 2,5\% diformulasikan dalam sediaan gel penyubur rambut dengan gelling agent carbophol 940 0,5\%,1\% dan 1,5\%. Penelitian ini bertujuan mengetahui apakah ekstrak air daun teh hijau $5 \%$ dan herba pegagan $2,5 \%$ dapat diformulasikan menjadi sediaan gel dan apakah gel yang mengandung kombinasi ekstrak tersebut mempunyai aktivitas sebagai penyubur rambut dan formula manakah yang memiliki aktivitas penyubur rambut yang paling optimum. Uji aktivitas penyubur rambut meliputi laju pertumbuhan rambut, percepatan pertumbuhan rambut dan bobot rambut. Hasil penelitian menunjukkan Campuran ekstrak air daun teh hijau $5 \%$ dan ekstrak air herba pegagan 2,5\% dengan gelling agent carbophol 940 0,5\%, 1\% dan 1,5\% dapat dibuat menjadi sediaan gel yang baik, dan yang memiliki aktifitas optimum adalah gel penyubur rambut yang menggunakan gelling agent carbophol 0,5\% dengan karakteristik warna coklat, aroma yang khas, homogen, nilai konsistensi 585,886 dyne $/ \mathrm{cm}^{2}$, viskositas $90.333 \mathrm{cps}$, sifat aliran plastis tikstropik, pH 5,56 , laju pertumbuhan $1,804 \mathrm{~cm}$ dalam 28 hari percepatan pertumbuhan rambut $0,1201 \mathrm{~cm} / \mathrm{hari}$ dan bobot rambut 0,0858 gram dalam 28 hari.
\end{abstract}

Kata Kunci : Gel penyubur rambut, teh hijau, pegagan, pertumbuhan rambut

\begin{abstract}
Healthy hair has a long cycle of hair growth and sufficient moisture where hair growth occurs because the cells of the matrix region or hair bulbs are continuously cleaving. Natural ingredients that are estimated to have potential in hair growth are green tea leaves (Camellia sinensis (L) $\mathrm{OK}$ ) and herb gotukola (Centella asiatica (L) Urban). In this research the water
\end{abstract}


exteact of green tea leaf $5 \%$ and $2.5 \%$ gotukola herbs extract are formulated in hair growth gel preparation with gelling agent carbophol 940 0.5\%, 1\% and $1.5 \%$. This study aims to find out whether green tea leaf extract of 5\% and herb pegagan $2.5 \%$ can be formulated into gel preparation and whether the gel containing the combination of extracts has activity as a fertilizer hair and which formula has the most optimum hair fertilizer. Test hair fertility activity includes hair growth rate, hair growth acceleration and hair weight. The results showed that the mixture of green tea leaf extract $5 \%$ and gotukola herbs extract $2.5 \%$ with gelling agent of carbophol 940 0,5\%,1\% and 1,5\% can be made into good gel preparation, and which has the optimum activity is a hair-fertilizing gel using gelling agent carbophol $0.5 \%$ with characteristic of brown color, distinctive aroma, homogeneous, consistency value of 585,886 dyne / cm2, viscosity 90,333 cps, plastic tikstropik flow properties, $\mathrm{pH} 5,56$, growth rate $1,804 \mathrm{~cm} 28$ days hair growth acceleration $0.1201 \mathrm{~cm} /$ day and hair weight 0.0858 grams in 28 days.

Keywords: Hair growth gel, green tea, gotukola, hair growth

\section{Penulis korespondensi:}

Lela Sulastri

Sekolah Tinggi Farmasi Muhammadiyah Cirebon

Jl Cideng Indah no 3 Cirebon

Email : lelasulastri79@yahoo.co.id /085860337189

\section{PENDAHULUAN}

Rambut sehat dan indah merupakan keinginan setiap manusia. Rambut sehat mempunyai siklus pertumbuhan rambut yang panjang dan kelembaban yang cukup. Pertumbuhan rambut terjadi karena sel-sel daerah matriks atau umbi rambut secara terus menerus membelah. Rambut mengalami proses pertumbuhan menjadi dewasa dan bertambah panjang lalu rontok dan kemudian terjadi pergantian rambut baru. Pertumbuhan rambut diharapkan berlangsung dengan optimal sehingga dihasilkan rambut yang sehat dan terhindar dari kerontokkan dan kebotakkan yang merupakan salah satu kelainan dalam rambut yang banyak terjadi baik pada pria maupun wanita. Hal ini umumnya disebabkan oleh kondisi fisiologis,stress emosional maupun fisik, kekurangan nutrisi, gangguan hormonal dan obat (Harrison 2009).

Daun teh hijau (Camellia sinensis (L) OK) mengandung sejumlah senyawa flavonoid yang terdiri dari epikatekin (EC), epikatekin galat (ECG), epigalokatekin galat (EGCG), galokatekin galat (GCG), galokatekin (GC), katekin galat (CG), katekin (C),dan selain itu adanya asam galat, vitamin $\mathrm{B}$ dan $\mathrm{C}$ yang mampu memperkuat akar rambut, mencegah kerontokan, menghambat radikal bebas, menetralkan racun, dan melindungi kulit kepala dari infeksi (Sandeep at al, 2012). Daun teh dalam bentuk ekstrak etanol 2,5\% yang diaplikasikan pada tikus jantan putih mempunyai aktivitas sebagai penyubur rambut yang optimal (Amin_at al, 2014). Teh hijau menurut Chung at al (2017) dikombinasikan dengan Houttuynia cordata Thund dan Perilla frutescens var acuta dengan dosis $200 \mathrm{mg} / \mathrm{kg}$ dan 400 $\mathrm{mg} / \mathrm{kg}$ pada mencit C57BL/6 yang diberikan secara oral selama 25 hari menunjukkan aktivitas sebagai peningkat pertumbuhan rambut yang diamati baik secara visual maupun mikroskopik.

Pegagan (Centella asiatica (L) Urban) dengan kandungan senyawa utama triterfenoid saponin yaitu asiatikoside, flavonoid, fitosterol, madecassid acid, madecassoside,asam asiatik,asam amino, asam lemak, steroid, tanin, alkaloid merupakan salah satu tumbuhan yang dapat digunakan dalam perawatan rambut rontok termasuk pada kebotakan laki-laki (Bylka 2013). Kaitannya penyubur rambut, dijelaskan dalam penelitian 
bahwa ekstrak etanol pegagan 4 bagian yang dikombinasikan dengan Citrus limonin (2 bagian), Cuscuta reflexa (10 bagian), Emblica officinalis (4 bagaian), Allium cepa (5 bagian), Lawsonia inermis ( 2 bagian), Azadirachta indica (5 bagian), Eclipta alba (5 bagian), Ocimum sanctum (3bagian) dan Eugenia caryophyllus ( 4 bagian) yang difomulasikan dalam bentuk sediaan ointment menunjukan adanya aktivitas pertumbuhan rambut (Sharma at al, 2010). Selain itu ekstrak pegagan $5 \% \mathrm{~b} / \mathrm{b}$ tunggal maupun yang dikombinasikan dengan ekstrak Emblica officinalis $5 \% \mathrm{~b} / \mathrm{b}$, ekstrak Aloe vera $5 \% \mathrm{~b} / \mathrm{b}$, ekstrak, Ocimum sanctum 5\% b/b, ekstrak Eclipta alba $5 \% \mathrm{~b} / \mathrm{b}$. dalam sediaan ointment yang diaplikasikan secara topikal pada tikus menunjukan aktivitas sebagai penyubur rambut (Jain at al, 2011).

Sediaan penyubur rambut dapat berupa sediaan larutan, emulsi dan sediaan setengah padat misalnya krim dan gel. Gel banyak disukai karena bersifat transparan, lembut, mudah dioleskan dan tidak meninggalkan lapisan berminyak pada permukaan kulit,menyejukkan, melembabkan, mudah terpenetrasi pada kulit, mudah melekat, mudaah mengering dan membentuk lapisan film yang tipis sehingga mudah dibersihkan dengan air (Panjaitan at al, 2012).Polimer-polimer yang biasa digunakan untuk membuat gel meliputi gom alam, tragakan, pektin, karagen, agar, asam alginat, serta bahan-bahan sintetis dan semisintetis seperti metil selulosa, hidroksi etil selulosa, karboksi metil selulosa, dan carbophol yang merupakan polimer vinil sintetis dengan gugus karboksil yang terionisasi (Maulina, Sugihartini, 2015). Carbophol 940 mempunyai efektifitas yang paling baik sebagai pengental pada viskositas yang tinggi, mempunyai tingkat kejernihan yang baik, menghasilkan gel yang mengkilap dengan konsentrasi penggunaan antara 0,5\% - 2\% (Rowe at al, 2009).

Pada penelitian ini ekstrak air daun teh hijau 5\% dan herba pegagan 2,5\% dikombinasikan dan diformulasikan dalam sediaan gel dengan menggunakan gelling agent carbophol 940 dalam 3 (tiga) formula dengan konsentrasi carbophol 940 0,5\%, $1 \%$ dan 1,5 $\%$. Ekstrak air daun teh hijau dikombinasikan dengan ekstrak herba pegagan diharapkan dapat memberikan efek sinergis dalam menyuburkan rambut karena senyawa-senyawa yang terkandung didalam kedua ekstrak tersebut memiliki aktivitas yang mendukung optimalnya pertunbuhan rambut. Dengan adanya senyawa EGCG dalam teh hijau menurut Kwon dalam Chung at al (2017) menjelaskan bahwa EGCG merangsang pertumbuhan rambut manusia dengan efek proliperatif dan anti apoptosis pada sel papilla dermal dan EGCE secara topikal dilaporkan mengalami penurunan apoptosis yang diinduksi testeron pada folikel rambut yang dicoba pada mencit. Secara umum mekanisme kerja daun teh hijau sebagai penyubur rambut adalah dengan menstimulasi dan meningkatkan proliferasi sel pada sel papilla dermal rambut, menekan produksi Tumor Necrosis Factor - alpha (TNF alpha) yang memicu terjadinya kebotakan dan adanya asam galat, Vitamin B dan C yang mampu memperkuat akar rambut, mencegah kerontokan, menghambat radikal bebas, menetralkan racun dan melindungi kulit kepala dari infeksi (Jain at al, 2011;Sandeep at al, 2012). Adapun mekanisme kerja herba pegagan sebagai penyubur rambut adalah dengan menebalkan epidermis, menyembuhkan peradangan di sekitar folikel rambut, memperbaiki sistem sirkulasi ke folikel sehingga suplai nutrisi dan oksigen ke folikel rambut lebih banyak. Selain itu pegagan dapat mengurangi efek dihydrotestosteron secara signifikan (Bylka at al, 2013).

Dengan demikian penelitian ini dilakukan untuk mengetahui apakah ekstrak air daun teh hijau $5 \%$ dan herba pegagan 2,5\% dapat diformulasikan menjadi sediaan gel dan apakah gel yang mengandung kombinasi ekstrak tersebut mempunyai aktivitas sebagai penyubur rambut serta formula manakah yang memiliki aktivitas penyubur rambut yang paling optimum. Uji aktivitas penyubur rambut meliputi laju pertumbuhan rambut, percepatan pertumbuhan rambut dan bobot rambut (Amin at al, 2014; Priskila 2012; Purwantini at al, 2008) 


\title{
METODE PENELITIAN
}

\begin{abstract}
Alat dan Bahan
Alat-alat yang digunakan dalam penelitian ini antara lain: timbangan analitik AND HR 120, Homogenizer Hsiangtai,Viskometer Brookfield RV , Penetrometer Koechler,pH meter Mettler Toledo, gunting rambut, pinset, solatip,lakban dan jangka sorong, wadah dari pot plastik. Bahan yang digunakan ekstrak air daun teh hijau ( PT Java Plant ), ekstrak air herba pegagan ( PT Java Plant),Carbophol 940 ( CV Mustika Lab ),Triaethanolamin ( CV Mustika Lab),Propilenglikol (CV Mustika Lab),Methyl Paraben ( CV Mustika Lab),Natrium Metabisulfit ( CV Mustika Lab), Etanol 70\% (PT Bratachem).
\end{abstract}

\section{Hewan Uji}

Hewan uji yang digunakan adalah kelinci putih jantan usia 3-4 bulan dengan bobot 2-3 kg dengan jumlah kelinci yang digunakan ditentukan dengan menggunakan rumus Federer : $(\mathrm{n}-1)(\mathrm{t}-1) \geq 15, \mathrm{t}$ menunjukkan jumlah perlakuan dan $\mathrm{n}$ menunjukkan jumlah hewan tiap perlakuan (Amin 2014; Priskila 2012; Purwantini 2008). Berdasarkan rumus empiris adalah 3 ekor kelinci putih jantan. Pada Punggung masing-masing kelinci dibuat 8 daerah pengolesan yaitu kontrol positif, kontrol normal, kontrol negatif 1 (basis formula 1), kontrol negatif 2 (basis formula 2), kontrol negatif 3 (basis formula 3), gel formula 1, gel formula 2 dan gel formula 3.

\section{Jalannya Penelitian}

\section{Optimasi kecepatan (rpm) pembuatan gel}

Carbophol 940 dengan berbagai variasi konsentrasi dikembangkan dalam air panas bersuhu lebih dari $80^{\circ} \mathrm{C}$, proses pengembangan dilakukan selama 30 menit. Ditambahkan TEA sedikit demi sedikit sambil dihomegenkan dengan homogenizer sampai terbentuk basis gel , kemudian tambahkan propilenglikol dan metil paraben yang sudah dilarutkan dengan sebagian propilenglikol ke dalam campuran tersebut . Ditambahkan natrium metabisulfit yang sudah dilarutkan dengan aquadest ke dalam campuran. Setelah homogen ditambahkan ekstrak air daun teh hijau dan ekstrak air herba pegagan yang sudah dilarutkan dengan aquadest, lalu tambahkan sisa aquadest. Setelah itu semua bahan dihomogenkan dengan dengan menggunakan homogenizer, optimasi kecepatan (rpm) 1000, 1100 dan 1200 rpm dengan waktu pengadukan 15 menit, kemudian diamati homogenitas sediaan pada setiap kecepatan pengadukan sehingga diperoleh kecepatan optimum.

\section{Optimasi waktu pengadukan pembuatan gel}

Carbophol 940 dengan berbagai variasi konsentrasi dikembangkan dalam air panas bersuhu lebih dari $80^{\circ} \mathrm{C}$, proses pengembangan dilakukan selama 30 menit. Ditambahkan TEA sedikit demi sedikit sambil dihomegenkan dengan homogenizer sampai terbentuk basis gel, kemudian tambahkan propilenglikol dan metil paraben yang sudah dilarutkan dengan sebagian propilenglikol ke dalam campuran tersebut . Ditambahkan natrium metabisulfit yang sudah dilarutkan dengan aquadest ke dalam campuran. Setelah homogen ditambahkan ekstrak air daun teh hijau dan ekstrak air herba pegagan yang sudah dilarutkan dengan aquadest, lalu tambahkan sisa aquadest. Setelah itu semua bahan dihomogenkan dengan menggunakan homogenizer, optimasi waktu pengadukan 5, 10 dan 15 menit dengan kecepatan yang sudah didapat dari optimasi kecepatan ( $\mathrm{rpm}$ ) pengadukan pembuatan gel, kemudian diamati homogenitas sediaan pada setiap waktu pengadukan sehingga diperoleh waktu pengadukan optimum. 


\section{Pembuatan sediaan gel}

Tabel I. Formula gel

\begin{tabular}{lccc}
\hline \multirow{2}{*}{\multicolumn{1}{c}{ BAHAN }} & \multicolumn{3}{c}{$\begin{array}{c}\text { JUMLAH } \\
(\boldsymbol{\%})\end{array}$} \\
\cline { 2 - 4 } & $\mathbf{F 1}$ & $\mathbf{F 2}$ & $\mathbf{F 3}$ \\
\hline Ekstrak daun teh hijau & 5 & 5 & 5 \\
Ekstrak herba pegagan & 2,5 & 2,5 & 2,5 \\
Carbophol 940 & 0,5 & 1 & 1,5 \\
Triaethanolamin & 0,5 & 1 & 1,5 \\
Propilenglicol & 10 & 10 & 10 \\
Methyl Paraben & 0,1 & 0,1 & 0,1 \\
Natrium Metabisulfit & 0,4 & 0,4 & 0,4 \\
Aquadest & $\mathrm{ad} \mathrm{100}$ & $\mathrm{ad} \mathrm{100}$ & $\mathrm{ad} 100$ \\
\hline
\end{tabular}

Carbophol 940 dengan berbagai variasi konsentrasi dikembangkan dalam air panas bersuhu lebih dari $80^{\circ} \mathrm{C}$, proses pengembangan dilakukan selama 30 menit. Ditambahkan TEA sedikit demi sedikit sambil dihomegenkan dengan homogenizer sampai terbentuk basis gel, kemudian tambahkan propilenglikol dan metil paraben yang sudah dilarutkan dengan sebagian propilenglikol ke dalam campuran tersebut . Ditambahkan natrium metabisulfit yang sudah dilarutkan dengan aquadest ke dalam campuran. Setelah homogen ditambahkan ekstrak air daun teh hijau dan ekstrak air herba pegagan yang sudah dilarutkan dengan aquadest, lalu tambahkan sisa aquadest. Setelah itu semua bahan dihomogenkan dengan menggunakan homogenizer dengan kecepatan dan waktu pengadukan yang optimal.

\section{Evaluasi Sediaan Gel \\ Organoleptik}

Pengamatan ini meliputi pengamatan terhadap warna dan aroma

\section{Homogenitas}

Sediaan gel dioleskan diatas kaca objek, kemudian dikatupkan dengan kaca objek lainnya dan dilihat apakah gel tersebut homogen atau tidak.

pH

Pemeriksaan $\mathrm{pH}$ menggunakan alat $\mathrm{pH}$ meter, yang dikalibrasi menggunakan larutan dapar $\mathrm{pH} 7$ dan $\mathrm{pH}$ 4. Satu gram sediaan yang akan diperiksa diencerkan dengan air suling hingga $10 \mathrm{ml}$. Elektroda $\mathrm{pH}$ meter dicelupkan ke dalam larutan yang diperiksa, jarum $\mathrm{pH}$ meter dibiarkan bergerak sampai menunjukan posisi tetap, $\mathrm{pH}$ yang ditunjukan jarum $\mathrm{pH}$ meter dicatat.

\section{Viskositas dan Sifat alir}

Penentuan viskositas bertujuan untuk mengetahui adanya perubahan kekentalan pada tiap formula gel. Penentuan viskositas dilakukan dengan menggunakan viskositas Brookfield tipe RV dengan mengamati angka pada skala viskometer dengan kecepatan tertentu. Sejumlah gel diletakkan dalam wadah berupa tabung silinder kaca (gelas piala) dan spindel yang sesuai dimasukkan sampai garis batas lalu diputar dengan kecepatan tertentu sampai jarum viskometer menunjukkan pada satu skala yang konstan. Tentukan viskositas dengan mengalikan skala yang diperoleh dengan faktor perkalian (Musryid 2017).

Penentuan sifat alir dilakukan dengan mengubah-ubah rpm sehingga didapat nilai viskositas pada berbagai rpm. Sifat alir dapat diketahui dengan cara membuat kurva antara kecepatan geser $(\mathrm{rpm})$ dengan gaya $\left(\right.$ dyne $\left./ \mathrm{cm}^{2}\right)$. Data yang diperoleh kemudian diplotkan 
pada kertas grafik antara gaya (x) dan kecepatan geser (y) kemudian ditentukan sifat alirnya (Musryid 2017).

\section{Konsistensi}

Penentuan konsistensi dilakukan dengan alat penetrometer, untuk setiap sediaan dilakukan sebanyak 3 kali dan hasilnya dirata-ratakan. Gel dimasukkan dengan jumlah yang agak berlebihan ke dalam wadah menggunakan spatula, ratakan permukaan dengan spatula. Letakan wadah dibawah kerucut makro dengan ujung kerucut langsung bersentuhan pada pusat permukaan gel. Pastikan bahwa tombol pengatur pada angka nol dan waktu penetrasi selama 5 detik. Catat nilai penetrasi $(\mathrm{mm})$ dan tentukan konsistensi dari sediaan tersebut (Kuncari at al, 2014).

\section{Persiapan Hewan Uji Setelah Adaptasi}

Setelah 1 (satu) minggu diadaptasikan, punggung kelinci dibersihkan dari rambut dengan cara dicukur hingga bersih,dibagi menjadi 8 bagian daerah pengolesan yang masingmasing berbentuk segi empat dengan luas area $2 \times 2,5 \mathrm{~cm}$ dan jarak antar daerah $1 \mathrm{~cm}$. Sebelum dilakukan pengolesan, punggung kelinci yang telah dicukur diolesi etanol $70 \%$ sebagai antiseptik. Daerah pengolesan pada punggung kelinci dapat dilihat pada gambar 1 dan pada setiap kelinci dilakukan pengacakan daerah pengolesan.

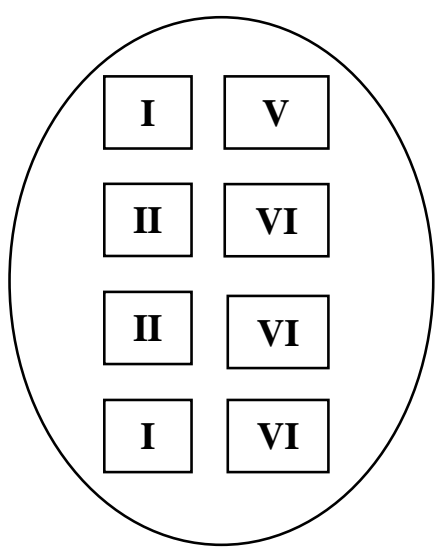

KELINCI 1

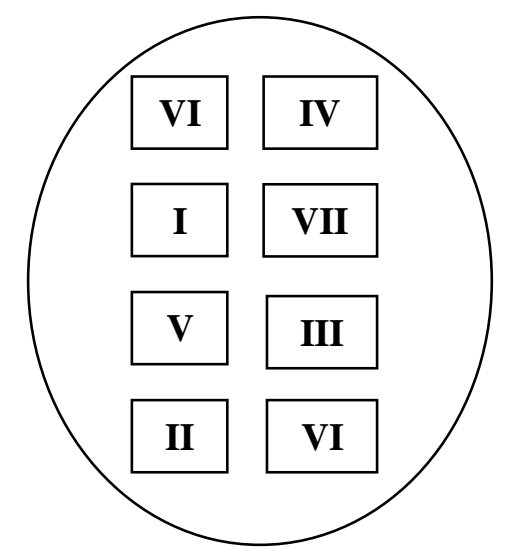

KELINCI 2

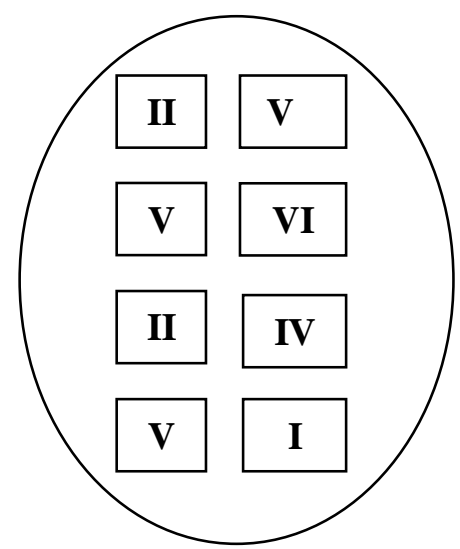

KELINCI 3

Gambar 1. Daerah pengolesan pada punggung kelinci

\section{Uji Aktivitas Gel Penyubur Rambut}

Uji aktivitas gel kombinasi ekstrak air daun teh hijau dan herba pegagan terhadap laju pertumbuhan rambut dilakukan dengan mengoleskan sediaan gel setiap hari 2 kali yaitu pagi dan sore dengan berat masing-masing 1 gram pada masing-masing daerah pengolesan. Hari pertama pengolesan dianggap hari ke-0. Pengamatan dilakukan selama 28 hari, dengan mengambil 6 helai rambut kelinci tiap 7 hari sekali,dihitung pada hari ke-7,ke-14, ke-21 dan ke-28. Rambut diambil dengan cara dipotong, diluruskan dan ditempelkan pada solatip, kemudian diukur panjang rambut dengan menggunakan jangka sorong. Pada hari ke-28 dilakukan pencukuran rambut masing-masing area kemudian ditimbang bobot rambut. Pada setiap kelinci terdapat pengacakan daerah pengolesan.

\section{Analisis Data}

Uji aktivitas penyubur rambut meliputi laju pertumbuhan rambut dan bobot rambut. Laju pertumbuhan rambut diperoleh dari panjang rambu. Data panjang rambut dan bobot rambut yang diperoleh selanjutnya dianalisis secara statistik untuk melihat apakah ada perbedaan bermakna antara daerah uji dengan kontrol. Untuk melihat normalitas dan 
homogenitas data, dilakukan uji normalitas (Saphiro-Wilk) dan uji homogenitas (Levene). Distribusi data yang normal dan homogen diolah untuk analisis ragam atau analysis of variance (ANOVA). Tujuan dilakukan uji ANOVA adalah untuk mengetahui ada atau tidaknya perbedaan yang bermakna secara statistik dari kelompok perlakuan secara keseluruhan. Selanjutnya, untuk melihat perbedaan bermakna secara statistik antar kelompok uji, maka dilakukan uji beda nyata terkecil (BNT). Distribusi data yang tidak normal atau tidak homogen dianalisis menggunakan statistik non parametik yaitu uji Kruskal Wallis. Kemudian dilanjutkan dengan uji Mann Whitney untuk melihat adanya perbedaan bermakna pada masing-masing kelompok uji dengan tingkat kepercayaan 95\% (Amin_at al, 2014).

HASIL DAN PEMBAHASAN

a. Optimasi Kecepatan dan waktu pengadukan

Tabel II. Hasil optimasi kecepatan pengadukan

\begin{tabular}{|c|c|c|c|c|}
\hline \multirow{2}{*}{$\begin{array}{c}\text { Waktu } \\
\text { pengadukan } \\
\text { (menit) }\end{array}$} & \multirow[t]{2}{*}{ Formula } & \multicolumn{3}{|c|}{ Kecepatan pengadukan (Rpm) } \\
\hline & & 1000 & 1100 & 1200 \\
\hline \multirow[t]{3}{*}{15 menit } & I & $\begin{array}{lr}\text { Kurang } & \text { homogen, } \\
\text { terbentuk } & \text { busa yang } \\
\text { hilang } & \text { setelah } \\
\text { penyimpanan } 1 \text { hari }\end{array}$ & $\begin{array}{l}\text { Homogen, terbentuk } \\
\text { busa yang hilang } \\
\text { setelah penyimpanan } 1 \\
\text { hari }\end{array}$ & $\begin{array}{l}\text { Homogen, terbentuk } \\
\text { busa yang hilang } \\
\text { setelah penyimpan } 1 \\
\text { hari }\end{array}$ \\
\hline & II & $\begin{array}{l}\text { Kurang homogen, } \\
\text { terbentuk gelembung } \\
\text { yang hilang setelah } \\
\text { penyimpanan } 1 \text { hari }\end{array}$ & $\begin{array}{l}\text { Homogen, terbentuk } \\
\text { gelembung rang } \\
\text { hilang penyimpanan } 1 \\
\text { hari }\end{array}$ & $\begin{array}{lr}\text { Homogen, } & \text { terbentuk } \\
\text { gelembung } & \text { yang } \\
\text { hilang } & \text { setelah } \\
\text { penyimpanan } & 1 \text { hari }\end{array}$ \\
\hline & III & $\begin{array}{lr}\text { Kurang } & \text { homogen, } \\
\text { terbentuk } & \text { busa yang } \\
\text { hilang } & \text { setelah } \\
\text { penyimpanan } 1 \text { hari }\end{array}$ & $\begin{array}{l}\text { Homogen, terbentuk } \\
\text { busa yang hilang } \\
\text { setelah penyimpanan } 1 \\
\text { hari }\end{array}$ & $\begin{array}{l}\text { Homogen, terbentuk } \\
\text { busa yang hilang } \\
\text { setelah penyimpanan } \\
1 \text { hari }\end{array}$ \\
\hline
\end{tabular}

Optimasi kecepatan pengadukan sediaan gel ini pada $1000 \mathrm{rpm}$ semua formula belum homogen, pada kecepatan pengadukan $1100 \mathrm{rpm}$ dan $1200 \mathrm{rpm}$ semua formula homogen. Semakin meningkat kecepatan pengadukan akan menambah banyaknya gelembung pada sediaan sehingga dapat mengurangi penampilan fisik. Dengan demikian dari hasil optimasi kecepatan pengadukan ini diperoleh kecepatan optimum $1100 \mathrm{rpm}$ karena semua formula sudah homogen. 
Tabel III. Hasil optimasi waktu pengadukan

\begin{tabular}{|c|c|c|c|c|}
\hline \multirow{2}{*}{$\begin{array}{c}\text { Kecepatan } \\
\text { pengadukan } \\
(\mathbf{R p m})\end{array}$} & \multirow[t]{2}{*}{ Formula } & \multicolumn{3}{|c|}{ Waktu pengadukan (menit) } \\
\hline & & 10 & 15 & 20 \\
\hline \multirow[t]{3}{*}{1100} & I & $\begin{array}{l}\text { Homogen, } r \text { terbentuk } \\
\text { busa yang hilang } \\
\text { setelah penyimpanan } 1 \\
\text { hari }\end{array}$ & $\begin{array}{l}\text { Homogen, terbentuk } \\
\text { busa yang hilang } \\
\text { setelah penyimpanan } \\
1 \text { hari }\end{array}$ & $\begin{array}{l}\text { Homogen, terbentuk } \\
\text { busa yang hilang } \\
\text { setelah penyimpanan } \\
1 \text { hari }\end{array}$ \\
\hline & II & $\begin{array}{l}\text { Kurang homogen, } \\
\text { terbentuk gelembung } \\
\text { yang hilang setelah } \\
\text { penyimpanan } 1 \text { hari }\end{array}$ & $\begin{array}{lr}\text { Homogen, } & \text { terbentuk } \\
\text { gelembung } & \text { yang } \\
\text { hilang } & \text { setelah } \\
\text { penyimpanan } 1 \text { hari }\end{array}$ & $\begin{array}{lr}\text { Homogen, terbentuk } \\
\text { gelembung } \quad \text { yang } \\
\text { hilang } & \text { setelah } \\
\text { penyimpanan } 1 \text { hari }\end{array}$ \\
\hline & III & $\begin{array}{l}\text { Kurang homogen, } \\
\text { terbentuk sedikit } \\
\text { gelembung yang hilang } \\
\text { setelah penyimpanan } 1 \\
\text { hari }\end{array}$ & $\begin{array}{l}\text { Homogen, terbentuk } \\
\text { sedikit gelembung } \\
\text { yang hilang setelah } \\
\text { penyimpanan } 1 \text { hari }\end{array}$ & $\begin{array}{l}\text { Homogen, terbentuk } \\
\text { sedikit gelembung } \\
\text { yang hilang setelah } \\
\text { penyimpanan } 1 \text { hari }\end{array}$ \\
\hline
\end{tabular}

Optimasi waktu pengadukan pada waktu 10 menit untuk formula 1 diperoleh sediaan gel yang homogen sedangkan untuk formula 2 dan 3 kurang homogen. Waktu pengadukan yang dipilih 15 menit, karena pada menit ke 15 semua formula diperoleh sediaan yang homogen. Semakin lama waktu pengadukan terbentuk gelembung yang terbentuk semakin banyak sehingga akan mengganggu penampilan fisik sediaan. Dengan demikian maka pada pembuatan gel digunakan kecepatan pengadukan $1100 \mathrm{rpm}$ dengan waktu pengadukan 15 menit.

b. Pembuatan Gel

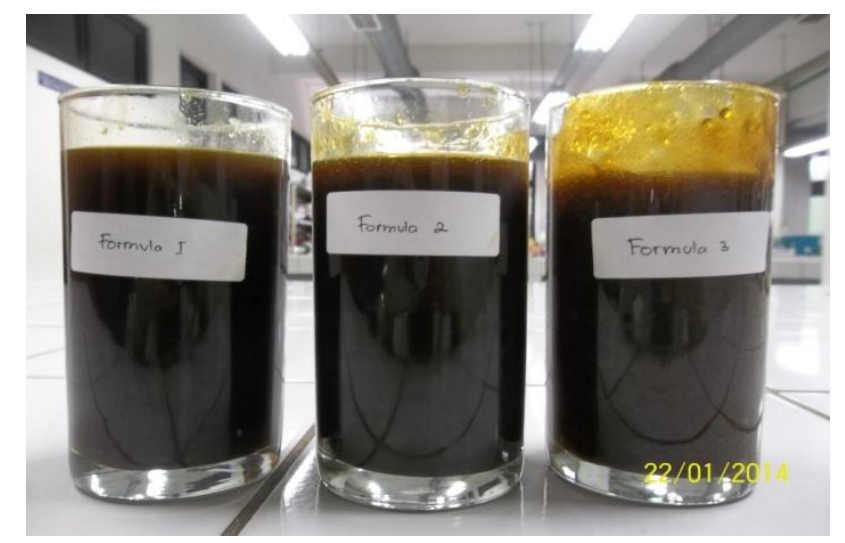

Gambar 2. Gel kombinasi ekstrak air daun teh hijau dan ekstrak air herba pegagan

Gel kombinasi ekstrak teh hijau dan ekstrak pegagan dibuat dengan menggunakan bahan pembentuk carbophol 940 dimana formula 1 menggunakan carbophol $0,5 \%$, formula 2 dengan carbophol $1 \%$ dan formula 3 carbophol 1,5\%. Digunakan carbophol 940 karena carbophol 940 mempunyai efektivitas yang paling baik sebagai pengental pada viskositas yang tinggi dan mempunyai tingkat kejernihan yang baik., dapat menghasilkan gel yang mengkilap dan dengan air atau hidroalkohol 
untuk gel topikal. Carbophol merupakan bahan dasar gel sintetis yang bila diformulasikan akan membentuk gel satu fase yang jernih (Maulina, Sugihartini 2015; Anggraini at al, 2013).

Trietanolamin ditambahkan sebagai bahan penetral untuk carbophol yang bersifat asam karena mengandung 56-86\% asam karboksilat. Mekanisme kerjanya dengan mengionisasi gugus karbopol ketika terpapar oleh cahaya dan menyebabkan oksidasi yang diperlihatkan dengan penurunan viskositas dispersi carbophol. Trietanolamin juga berfungsi sebagai bahan penstabil dan pengembang dari carbophol dan mencegah rusaknya dispersi carbophol ketika terpapar oleh cahaya yang dapat menyebabkan gel menjadi keruh (Anggraini at al, 2013).

Propilenglikol ditambahkan sebagai humektan yang berfungsi untuk meningkatkan kelembutan dan daya sebar serta mencegah penguapan (kehilangan air). Metil paraben dimaksudkan sebagai pengawet, hal ini disebabkan karena sebagai medium pendispersi air yang sangat rentan terhadap pertumbuhan mikroba. Natrium metabisulfit ditambahkan sebagai antioksidan yang berfungsi untuk mencegah reaksi oksidasi dari sediaan gel (Kuncari at al, 2014).

c. Evaluasi sediaan gel

Hasil pengamatan organoleptik menunjukkan ketiga formula memiliki warna coklat tua dengan aroma khas,dengan homogenitas ketiga sediaan homogen , tidak terjadi pemisahan antara bahan dengan basis gel. Hal tersebut dikarenakan telah dilakukannya uji optimasi waktu pengadukan dan kecepatan yang optimal untuk membuat sediaan menjadi homogen.

Berdasarkan hasil pemeriksaan $\mathrm{pH}$ menunjukan semua formula mempunyai $\mathrm{pH}$ berada dalam rentang $\mathrm{pH}$ normal kulit yang diperbolehkan untuk digunakan pada kulit yaitu antara 4,5-6,5 yaitu untuk formula 15,56 , formula 25,01 dan formula 34,87 (Kuncari at al, 2014).

Pada pemeriksaan konsistensi sediaan gel diperoleh rata-rata angka penetrasi berturut-turut untuk formula 1, formula 2 dan formula 3 adalah 354,3, 304 dan 282 dengan nilai konsistensi 585,886 dyne $/ \mathrm{cm}^{2}, 682,998$ dyne $/ \mathrm{cm}^{2}$ dan $736,301 \mathrm{dyne} / \mathrm{cm}^{2}$. Berdasarkan hasil pengukuran angka penetrasi dengan penetrometer dihasilkan ketiga formula tersebut mempunyai angka penetrasi yang berbeda-beda dengan demikian maka konsistensi ketiga formula tersebut juga berbeda. Semua formula nilai konsistensinya berada dalam kisaran 100-1000 dyne/ $\mathrm{cm}^{2}$. Hal ini menunjukkan bahwa semua sediaan gel bersifat lembut dan dapat menyebar. Nilai konsistensi yang kecil menunjukan angka penetrasi yang besar artinya kemampuan atau daya sebar besar (Kuncari at al, 2014).

Berdasarkan pengamatan viskositas gel kombinasi ekstrak air daun teh hijau dan ekstrak air herba pegagan pada 0,5 rpm dengan menggunakan viskometer Brookfield tipe RV dimana formula 1 menggunakan spindel 3 dengan viskositas 90.333 cps, formula 2 menggunakan spindel 6 dengan viskositas $1.142 .666,66 \mathrm{cps}$ dan formula III menggunakan spindel 7 dengan viskositas 2.234.666,66 cps. Dari pengamatan viskositas dari ketiga formula tersebut terdapat peningkatan viskositas. Hal ini menunjukan bahwa semakin besar konsentrasi carbophol 940 yang digunakan maka viskositas yang diperoleh semakin tinggi karena jumlah carbophol 940 yang menjerat air akan semakin banyak.

Hasil evaluasi sifat alir, semua formula menunjukan aliran plastis tiksotropik. Pada kurva sifat alir terlihat bahwa kurva menurun berada di sebelah kiri kurva menaik (Gambar 3). Hal ini menunjukan bahwa sediaan tersebut memiliki nilai viskositas yang lebih rendah pada setiap harga kecepatan geser dari kurva yang menurun dibandingkan dengan kurva yang menaik. Hal tersebut lebih dikenal dengan tiksotropik karena adanya 
pemecahan struktur yang tidak terbentuk kembali dengan segera jika tekanan tersebut dihilangkan atau dikurangi.Tiksotropik merupakan suatu sifat alir yang diharapkan dalam sediaan semi solid karena mempunyai konsistensi yang tinggi namun dapat dengan mudah dituang dan mudah tersebar (Mursyid 2017).

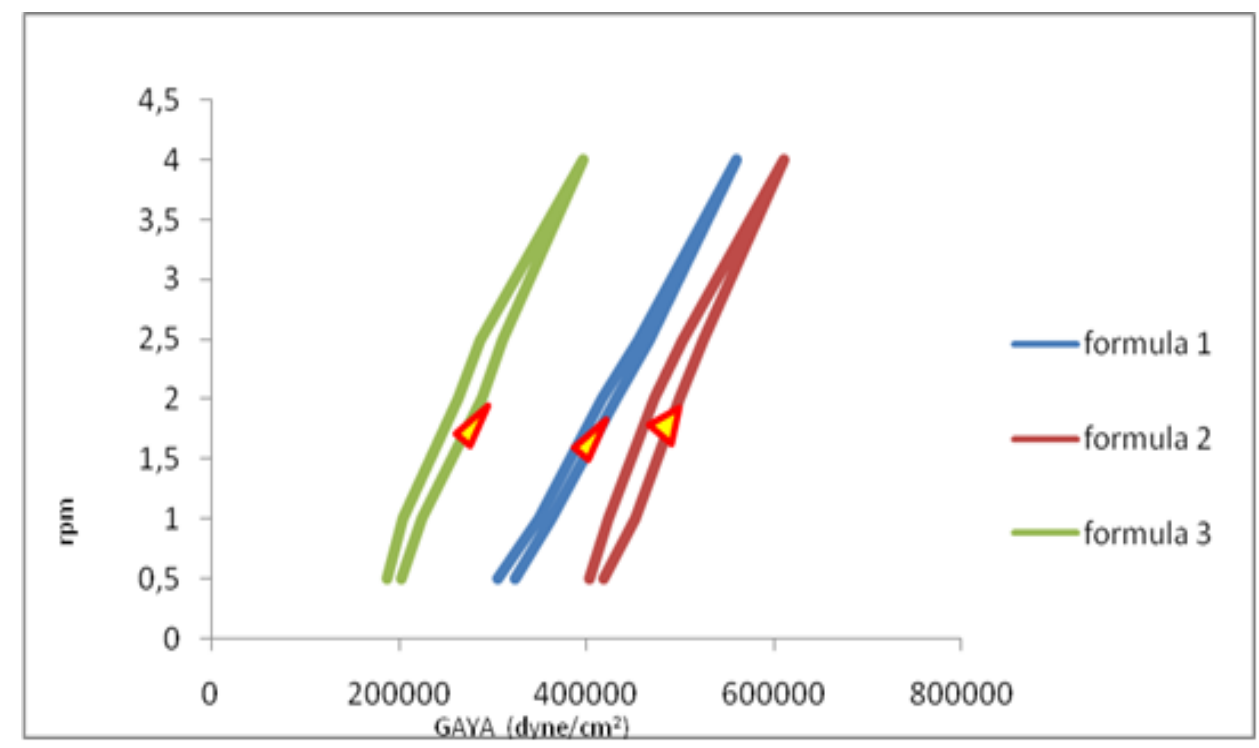

Gambar 3. Kurva sifat alir gel

d. Uji aktivitas penyubur rambut sediaan gel kombinasi ekstrak air daun teh hijau dan ekstrak air herba pegagan

\section{Laju Pertumbuhan rambut}

Tabel IV. Laju pertumbuhan rambut kelinci yang diberi gel kombinasi ekstrak air daun teh hijau dan ekstrak air herba pegagan

\begin{tabular}{lcccc}
\hline \multicolumn{1}{c}{ Perlakuan } & \multicolumn{5}{c}{ Rata-rata panjang $(\mathbf{c m}) \pm$ sd } & \\
\cline { 2 - 5 } & Hari ke- 7 & Hari ke- 14 & Hari ke- 21 & Hari ke- 28 \\
\hline Kontrol normal & $0,473 \pm 0,39$ & $0,653 \pm 0,19$ & $1,072 \pm 0,10$ & $1,248 \pm 0,19$ \\
Kontrol positif & $0,876 \pm 0,23$ & $1,018 \pm 0,41$ & $1,254 \pm 0,41$ & $1,463 \pm 0,53$ \\
Formula 1 & $0,841 \pm 0,21$ & $1,185 \pm 0,28$ & $1,637 \pm 0,22$ & $1,804 \pm 0,24$ \\
Formula 2 & $0,831 \pm 0,19$ & $1,053 \pm 0,23$ & $1,278 \pm 0,14$ & $1,448 \pm 0,20$ \\
Formula 3 & $0,799 \pm 0,20$ & $0,976 \pm 0,28$ & $1,201 \pm 0,11$ & $1,349 \pm 0,10$ \\
Basis formula 1 & $0,584 \pm 0,08$ & $0,647 \pm 0,08$ & $0,767 \pm 0,09$ & $0,873 \pm 0,06$ \\
Basis formula 2 & $0,517 \pm 0,05$ & $0,591 \pm 0,07$ & $0,626 \pm 0,05$ & $0,768 \pm 0,05$ \\
Basis Formula 3 & $0,468 \pm 0,10$ & $0,535 \pm 0,09$ & $0,587 \pm 0,09$ & $0,682 \pm 0,01$ \\
\hline
\end{tabular}

Panjang rambut kelinci yang tumbuh setelah diberi gel kombinasi ekstrak air daun teh hijau dan ekstrak air herba pegagan selama 28 hari menunjukkan bahwa setiap minggunya mengalami pertambahan panjang rambut, begitu juga halnya dengan kontrol normal, kontrol positif dan kontrol negatif (basis gel) sebagaimana terlihat pada tabel 4 . Pada tabel 4 terlihat basis gel (kontrol negatif) yang digunakan mengalami pertumbuhan yang lambat ditunjukan dengan panjang rambut yang dihasilkan lebih pendek dan dibawah kontrol normal, dalam hal ini dapat dikatakan bahwa basis gel tidak mempunyai aktivitas terhadap pertumbuhan rambut. Kontrol normal 
menggambarkan pertumbuhan rambut normal karena tidak menerima perlakuan apapun dan terlihat bahwa kontrol normal pertumbuhannya juga lambat, yang ditunjukkan dengan panjang rambut dibawah kontrol positif dan sediaan gel. Gel dibuat dengan bahan pembentuk gel carbophol 940, dimana semua sediaan gel yang mengandung kombinasi ekstrak tersebut menunjukkan aktivitasnya dalam pertumbuhan rambut. Dimana formula 1 menghasilkan rata-rata panjang rambut yang lebih panjang daripada formula 2 ,formula 3 , kontrol normal dan kontrol positif.

Rata rata panjang rambut sampai dengan hari ke-28 menunjukan data tidak terdistribusi normal dan tidak homogen sehingga analisa statistik menggunakan uji Kruskal Wallis yang menunjukan adanya perbedaan bermakna dan dilanjutkan dengan uji Mann-Whitney . Hasil uji Mann-Whitney menunjukkan adanya perbedaan bermakna pada kontrol normal dengan formula $1(\mathrm{p}<0,05)$, hal ini menggambarkan adanya pertumbuhan rambut yang siginifikan secara statistik pada formula 1 jika dibandingkan dengan kontrol normal.Hasil uji Mann-Whitney rata-rata panjang rambut pada kontrol positif tidak menunjukan perbedaan bermakna $(p>0,05)$ jika dibandingkan dengan formula 1 , dengan demikian formula 1 memiliki aktivitas pertumbuhan rambut yang sama efektif dengan kontrol positif. Hasil analisa lainnya formula 1 dibandingkan dengan formula 2 tidak menunjukan perbedaan berkna $(p>0,05)$ dan dengan formula 3 menunjukkan adanya perbedaan bermakna $(\mathrm{p}<0,05)$. Dengan demikian formula 1 dan formula 2 memiliki aktivitas sebagai penyubur rambut dan yang paling efektif sampai dengan hari ke-28 adalah formula 1 karena rata-rata panjang rambut yang dihasilkan lebih panjang daripada formula 2 .

\section{Percepatan pertumbuhan rambut}

Tabel V. Percepatan pertumbuhan rambut kelinci yang diberi gel kombinasi ekstrak air daun teh hijau dan ekstrak air herba pegagan

\begin{tabular}{lccccc}
\hline \multirow{2}{*}{ Perlakuan } & \multicolumn{6}{c}{ Laju pertumbuhan rambut cm/hari) } & & \\
\cline { 2 - 6 } & Hari ke- 0 & Hari ke- 7 & Hari ke- 14 & Hari ke- 21 & Hari ke- 28 \\
\hline Kontrol normal & 0 & 0,0676 & 0,0466 & 0,0510 & 0,0446 \\
Kontrol positif & 0 & 0,1251 & 0,0727 & 0,0597 & 0,0523 \\
Formula 1 & 0 & 0,1201 & 0,0846 & 0,0780 & 0,0644 \\
Formula 2 & 0 & 0,1187 & 0,0752 & 0,0609 & 0,0517 \\
Formula 3 & 0 & 0,1141 & 0,0697 & 0,0572 & 0,0482 \\
Basis formula 1 & 0 & 0,0834 & 0,0462 & 0,0365 & 0,0312 \\
Basis formula 2 & 0 & 0,0739 & 0,0422 & 0,0298 & 0,0274 \\
Basis Formula 3 & 0 & 0,0669 & 0,0382 & 0,0280 & 0,0244 \\
\hline
\end{tabular}




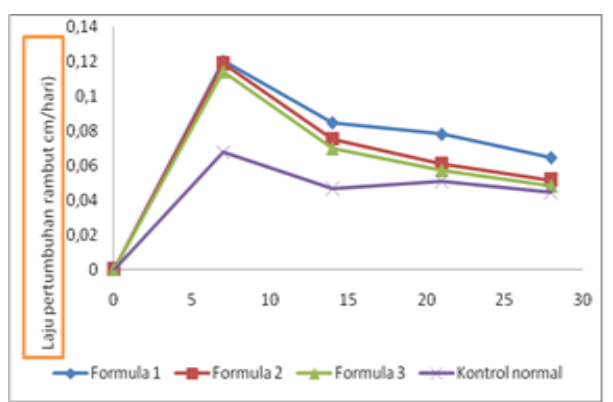

Gambar

4. Grafik percepatan pertumbuhan rambut kelinci pada gel kombinasi ekstrak dibandingkan dengan kontrol normal

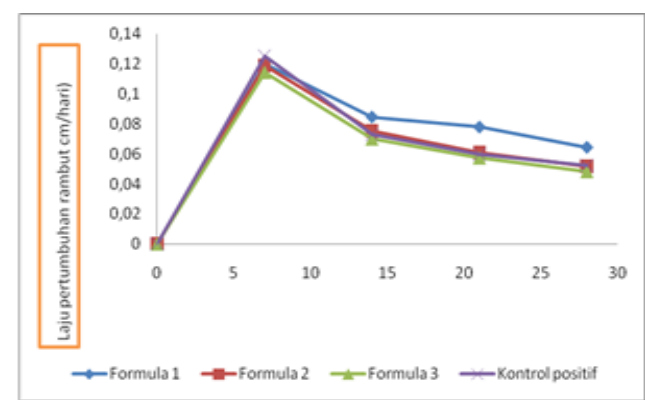

Gambar

5. Grafik percepatan pertumbuhan rambut kelinci pada gel kombinasi ekstrak dibandingkan dengan kontrol posiitf

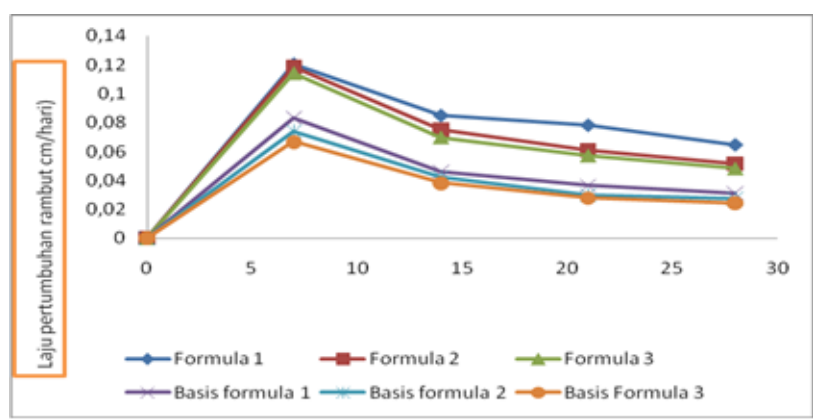

Gambar 6. Grafik percepatan pertumbuhan rambut kelinci pada gel kombinasi ekstrak dibandingkan dengan kontrol negatif

Berdasarkan gambar 4,5 dan 6 menunjukkan bahwa percepatan pertumbuhan rambut yang paling cepat pada kontrol normal, kontrof positif, kontrol negatif dan ketiga formula gel terjadi pada hari yang sama yaitu hari ke-7dimana percepatan pertumbuhan rambut yang paling tinggi dimiliki oleh kontrol positif yaitu 0,1251 $\mathrm{cm} /$ hari, sedangkan ketiga formula gel tersebut menunjukkan percepatan pertumbuhan rambut yang berhimpit dengan kontrol positif dan yang terbesar dimiliki oleh formula 1 yaitu $0,1201 \mathrm{~cm} /$ hari. Adapun pertumbuhan rambut normal yang digambarkan oleh kontrol normal memiliki percepatan pertumbuhan rambut dibawah kontrol positif, ketiga formula gel daan kontrol negatif dan kontrol negatif berada dibawah ketiga formula gel tersebut. Selanjutnya pada hari ke-8 sampai dengan hari ke-28 semua mengalami penurunan secara perlahan-lahan, dimana terlihat bahwa formula 1 penurunannya lebih kecil dibandingkan kontrol positif, formula 2, 3 serta kontrol negatif dan sampai hari ke-28 formula 1 memiliki percepatan pertumbuhan rambut yang paling besar diantara kontrol positif , formula 2, 3 serta kontrol positif. Berdasarkan data tersebut maka semua formula gel dapat meningkatkan laju pertumbuhan rambut dengan pola yang sama, sehingga dapat memperlihatkan pertambahan panjang yang signifikan, dengan demikian maka formula 1 merupakan formula yang paling efektif. 


\section{Bobot Rambut}

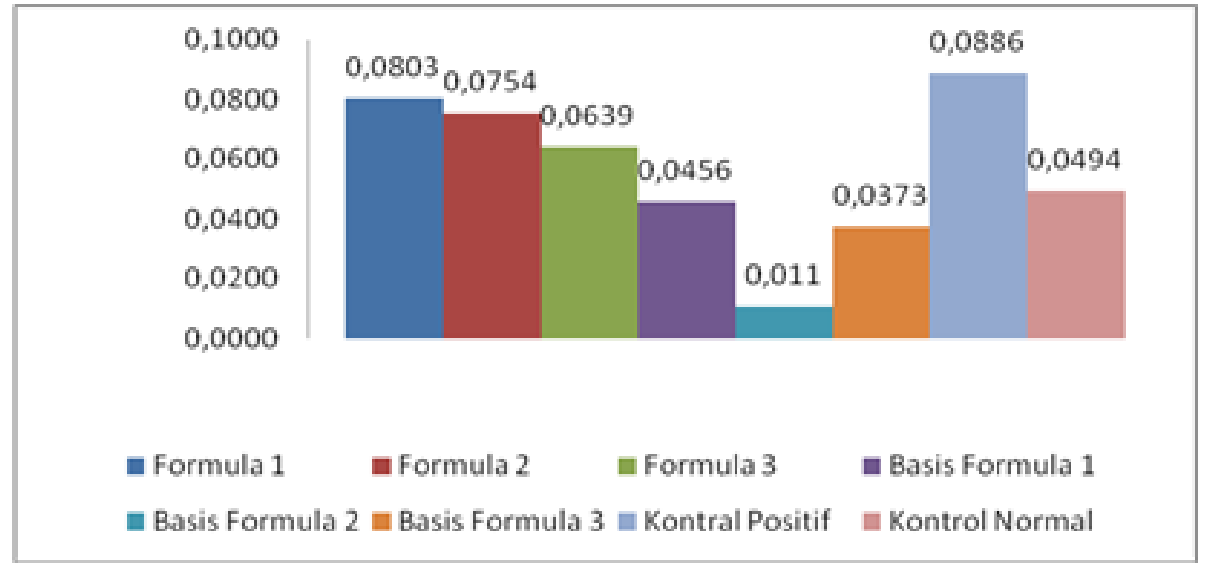

Gambar 7. Diagram batang bobot rambut kelinci yang diberi gel kombinasi ekstrak air teh hijau dan ekstrak air herba pegagan

Pada hari ke-28 dilakukan pengukuran bobot rambut,dengan tujuan untuk mengetahui kelebatan rambut. Data rata-rata bobot rambut dapat dilihat pada gambar 7 . Hasil analisa statistik dengan uji Anava menunjukkan bahwa terdapat perbedaan yang bermakna/signifikan dari rata-rata berat rambut masing-masing kelompok kelinci ( $\mathrm{p}<$ 0,05). Berdasarkan uji Mann Whitney menunjukkan adanya perbedaan yang bermakna antara formula 1 jika dibandingkan dengan basis formula 1 , basis formula 2 , basis formula 3 dan kontrol normal $(\mathrm{p}<\alpha(0,05)$. Hal ini menunjukan bahwa formula 1 menghasilkan bobot rambut yang secara statistik berbeda signifikan dengan basis formula 1, basis formula 2 , basis formula 3 dan kontrol normal. Dalam hal ini formula 1 ( 0,0869 gram) mempunyai bobot rambut yang lebih berat daripada basis formula 1 ( 0,0456 gram) , basis formula $2(0,0363$ gram $)$, basis formula $3(0,0373)$ dan kontrol normal $(0,0494)$, dengan demikian formula 1 menghasilkan rambut yang cukup lebat.Selain itu terdapat perbedaan bermakna juga antara formula 2 jika dibandingkan dengan basis formula 1 , basis formula 2 dan basis formula 3 dengan nilai signifikan $<\alpha$ $(0,05)$. Hal ini menunjukan bahwa formula 2 mempunyai bobot rambut yang secara statistik berbeda signifikan dengan basis formula 1, basis formula 2 dan basis formula 3 .

Kontrol positif jika dibandingkan dengan formula 1 dan formula 2 secara statistik menunjukan tidak adanya perbedaan yang bermakna $(p>0,05)$. Hal ini juga menunjukan bahwa bobot rambut yang dihasilkan kontrol positif secara statistik sama dengan formula 1 dan formula 2 . Untuk melihat yang terbaik dari parameter bobot dapat dilihat pada analisa statistik yang membandingkan antara kontrol normal dengan perlakuan lainnya, dimana terdapat perbedaan yang signifikan antara kontrol normal yang dibandingkan dengan formula 1 dan kontrol positif $(\mathrm{p}<0,05$. Hal ini menunjukkan kontrol normal yang merupakan pertumbuhan normal memiliki bobot rambut yang signifikan/ berbeda bermakna dengan formula 1 dan kontrol positif. Dengan demikian maka sediaan gel yang optimal dari ketiga formula tersebut adalah formula 1. karena bobot rambut yang dihasikkannya lebih berat. Bobot rambut besar menunjukan ketebalan.diameter rambut lebih besar pula.

Gel penyubur rambut yang efektif adalah yang dapat memberikan laju pertumbuhan dan percepatan pertumbuhan rambut yang cepat, dan menghasilkan diameter/ketebalan rambut yang besar. Berdasarkan parameter tersebut formula 1 yang mengandung ekstrak teh hijau $5 \%$ dan ekstrak pegagan $2,5 \%$ dengan gelling agent carbophol $9400,5 \%$ memiliki laju pertumbuhan dan percepatan pertumbuhan rambut serta bobot rambut yang lebih besar daripada formula 2 dan formula 3 . Hal ini menunjukan adanya perbedaan penggunaan carbophol dalam formula gel yang mempengaruhi aktivitas dari sediaan gel masing-masing. Semakin besar penggunaan 
carbophol menyebabkan aktivitasnya terhadap laju pertumbuhan rambut menurun. Gel dengan konsentrasi carbophol yang lebih besar memiliki viskositas yang lebih tinggi dan angka penetrasi yang lebih kecil dibandingkan formula 2 dan 3. Angka penetrasi yang kecil menunjukan konsisntensi yang besar sehingga menyebabkan kemampuan daya sebarnya kecil.Oleh karena itu fornula yang menggunakan carbophol lebih banyak menghasilkan laju pertumbuhan rambut yang lambat.

\section{KESIMPULAN}

Campuran ekstrak air daun teh hijau $5 \%$ dan ekstrak air herba pegagan 2,5\% dengan gelling agent carbophol 940 0,5\%, 1\% dan 1,5\% dapat dibuat menjadi sediaan gel yang baik, dan yang memiliki aktivitas optimum adalah gel penyubur rambut yang menggunakan gelling agent carbophol 0,5\% dengan karakteristik warna coklat, aroma yang khas, homogen, nilai konsistensi $585,886 \mathrm{dyne} / \mathrm{cm}^{2}$, viskositas $90.333 \mathrm{cps}$, sifat aliran plastis tikstropik, pH 5,56, laju pertumbuhan 1,804 cm dalam 28 hari percepatan pertumbuhan rambut $0,1201 \mathrm{~cm} /$ hari dan bobot rambut 0,0858 gram dalam 28 hari.

\section{DAFTAR PUSTAKA}

Amin J.,Simamora E L P.,Anwar E.,Djajadisastra J, 2014. Green Tea ( Camelia sinensis L) Ethanolic Extract As Hair Tonic In Nutraceutical; Physical Stability, Hair Growth Activity On Rats, And Safety Test, International Journal of Pharmacy and Pharmaceutical Sciences. 6 (5) : 94-99.

Anggraini, D.,Rahmawati, N., Hafsah,S., 2013, Formulasi Gel Antijerawat Dari Ekstrak Etil Asetat Gambir, Jurnal Penelitian Farmasi Indonesia 1 (2) 62-66.

Bylka, W., Znajdek-Awizen,P., Studzinska- Sroka. E., Brzezinska. M., 2013, Centella asiatica in Cosmetology, Postep Derm Alergol XXX, $1: 46-49$

Chung, M.S., Bae, W.J., Choi, S.W., Lee, K.W., Jeong, H.C., Bashraheel,F., Jeon, S.H., Jung, J.W., Yoon, B., Kwon, E.B., Hyun A Oh., Hwang, S.Y., Kim, S.W., 2017, An Asian Traditional Herbal Complex Containing Houttuynia cordata Thunb, Perilla frustescens Var. Acuta and Green Tea Stimulates Hair Growth In Mice, BMC Complementary and Alternative Medicine , 17 (515) 1-11.

Harrison, S. , \& Bergfeld, W., 2009, Diffuse Hair Loss: Its Triggers and Management, Ceveland Clinic Journal of Medicine, 2009; 76 (6), 361-367.

Jain, R., Jain, K.N., Singh, N.,Gnanachandran, A.K.,Glokulan, P.D., 2011, Development and Evaluation of Polyherbal Ointment For Hair Growth Activity, International Journal Of Pharmacy and Pharmaceutical Science, 3 (2) $180-182$.

Kuncari, E.S.,Iskandarsyah., Praptiwi., 2014, Evaluasi, Uji stabilitas Fisik Dan Sineresis Sediaan Gel Yang Mengandung Minoksisdil, Apigenin Dan Perasan Herba Seledri (Apium graveolens L), Buletin Peneliti Kesehatan 42 (4) 213-222.

Maulina, L.,Sugihartini,N., 2015, FormulasiGel Ekstrak Etanol Kulit Buah Manggis (Garcinia mangostana L) Dengan Variasi Gelling Agent Sebagai Sediaan Luka Bakar, Pharmaciana, 5 (1), 43-52.

Mursyid, M.A., 2017 Evaluasi Stabilitas Fisik Dan Profil Difusi Sediaan Gel (Minyak Zaitun), Jurnal Fitofarmaka Indonesia 4 (1) 205-211. 
Panjaitan, EN.,Saragih, A.,Purba,D., 2012, Formulasi Gel Dari Ekstrak Rimpang Jahe Merah (Zingiber officinale Roscoe), Jurnal of Pharmaceutics and Pharmacology, 1(1) 9-20.

Priskil,V.,2012, Uji Stabilitas Fisik Dan Uji Aktivitas Pertumbuhan Rambut Tikus Jantam Putih Dari Sediaan Hair Tonik Yang Mengandung Ekstrak Air Bonggol Pisang Kepok (Musa balbisiana). (Skripsi) Fakultas Farmasi Universitas Indonesia 28-30.

Sandeep, K., Nisha,S., Shweta.,Archana.,2012, Green Tea Polyphenols : Versatile Cosmetic Ingredient, International Journal of Advanced Research In Pharmaceutical \& Bio Sciences, 1 (3) 147-151.

Rowe,R.C.,Sheskey,P.I.,Quinn,M.E.,2009, Handbook of Pharmaceutical Excipient, 6th edition, Pharmaceutical Press and Amerucan Pharmacists Association,USA, $110,113,441,445,754,755$.

Sharma, A.K., Agarwal, V., Kumar, R., Kaushik, K., Bharwadj, P., 2010, Development And Evaluation Of Herbal Formulation For Hair Growth, Inter J Curr Trends Sci Tech, 1(3): 147-151. 
